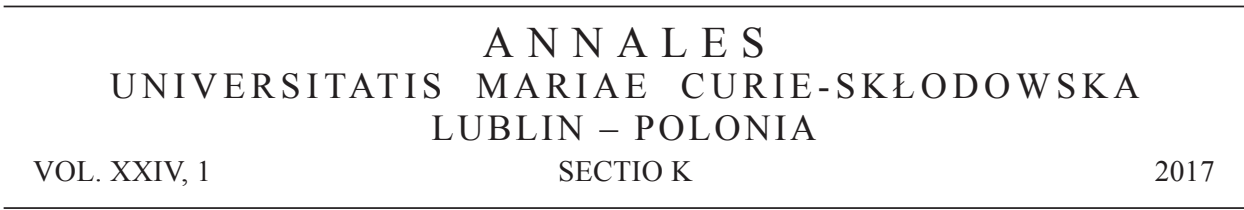

Faculty of Political Science and Journalism, Adam Mickiewicz University in Poznań, Poland

\title{
Direct Democracy and Its Tools in the Face of Use of New Technologies*
}

\begin{abstract}
Given the dynamic development of the new media, in particular the Internet, the social, economic and cultural fields of modern life are undergoing changes as well as many others. New technologies have also had an impact on political and civil activities. Direct democracy and its tools are subjects of changes resulting from the development of new technologies. The consequence of ICT impact on direct democracy is appearing a notion of "electronic (or digital) direct democracy". The electronic form of direct governance has ICT-based tools of exercising power that are or can be used by citizens as an instrument for co-participating in shaping political life and decisions. These considerations aim to answer the question of how the use of the Internet can influence modern democracy, in particular the direct form of governance. The author intends to answer the following research questions: how are the instruments of direct democracy, such as referenda, popular initiative and popular assembly (and, by this token, direct democracy) changing (or how they might change) following the application of the Internet or other ICTs? What opportunities and threats might ICTs employed in direct democracy bring for democracy, authorities and society?
\end{abstract}

Key words: electronic direct democracy, e-referendum, e-voting, e-initiative

* This article has been prepared within a research project: "Demokracja bezpośrednia w Europie Środkowej i Wschodniej po 1989 roku: wymiar formalnoprawny i praktyczny. Analiza politologiczna" (UMO-2014/15/B/HS5/01866), financed by the National Science Centre in Poland. 


\section{INTRODUCTION}

Although democracy is among the most popular terms in the political dictionary used in the contemporary world, it has to be admitted that its meaning has not been precisely determined. From the etymological point of view, the term "democracy" (Gr. dēmokratía - from dèmos, "people" and krátos, "force", "power", "governance") means the rule of the people or the power of the people. Democracy is, therefore, a form of governance where the people exercise power. The name "democracy" is applied to the forms of the political system of the state and the power it has, the mechanisms applied to exercise this power and the participation of society. A majority of political systems claim to operate within the framework of democracy despite their ideological interpretations [Świętojański 1990: 20-23]. In the opinion of many theoreticians of politics, no other political system, one that laid the foundations of human history, has had such a revolutionary impact on the hopes of ordinary people as democracy [Novak 2001: 25], constituting a certain principle that organizes life and applies not only to the realm of politics but exerts an influence on other fields of social life as well.

It is generally assumed that democracy can be understood, among other things, as a political system founded on the tenet that the people are the source and subject (holder) of supreme power [Bartyzel 2002: 7]. On top of the principle of the tripartite division of power, and the rule of law, the principle of the sovereignty of the nation is essential for a democratic state to operate. According to this principle, supreme power is exercised by the nation, understood as a legal community created by all citizens. The principle of the sovereignty of the nation can be implemented directly or indirectly. Exercising direct power is manifested, among other things, in the right to a referendum or popular initiative, whereas indirect power is exercised by means of elections and the selection of deputies who receive a mandate to exercise power on behalf of society [Konstytucja Rzeczypospolitej Polskiej...].

Given the dynamic development of the new media, in particular the Internet, the social, economic and cultural fields of modern life are undergoing changes as well as many others. New technologies have also had an impact on political and civil activities.

The application of information and communication technologies (ICT) transforms democracy as such, and the tools and instruments it employs. Probably the most observable change that accompanies democracy pertains to electoral campaigns, where both political parties and politicians assign an increasingly important role to the Internet as currently the most popular information and communication platform. Additionally, the Internet has a considerable influence on the electoral process, in particular in those countries where voters are able to vote electronically. The Internet facilitates greater civic participation in political life. Benjamin Barber believes that direct civic participation in making crucial decisions may be a remedy to the imperfect representative democracy and contribute to building a strong and stable 
democracy. Barber claims that democracy has to give freedom to citizens and, being a form of civic commitment, it is a source of civic virtues and community [Barber 1984: 179-180].

These considerations aim to answer the question of how the use of the Internet can influence modern democracy, in particular the direct form of governance. The author intends to answer the following research questions: how are the instruments of direct democracy, such as referenda, popular initiative and popular assembly (and, by this token, direct democracy) changing (or how they might change) following the application of the Internet or other ICTs? What opportunities and threats might ICTs employed in direct democracy bring for democracy, authorities and society? The considerations are based on theoretical aspects of direct democracy as well as on combining practical dimension of direct democratic tools with the development of information and communication technologies. In the article several good practices of the use of electronic forms of direct democracy will be mentioned.

\section{DIRECT DEMOCRACY AND NEW TECHNOLOGIES}

The name direct democracy is assigned to these forms of governance where all eligible citizens participate in the process of political decision making. The direct form of governance is deemed to be the fullest form of democracy, and the literature on political science and law quotes numerous concepts and interpretations of it. The majority of authors deliberating on this form of democracy indicate that the citizens play a direct role in exercising their public functions.

A majority of theoreticians of democracy believe that the tenets of direct democracy cannot be fulfilled if citizens are not significantly involved in the process of decision-making in their state. Civic involvement is also suggested as having a positive as well as a negative impact on many aspects of political life. The proponents of general participation argue that civic participation in important national elections is a reflection and reinforcement of democratic legitimization, thereby helping to curb violence and orient it towards proper competition [Powell Jr 1982: 2; Pennock 1979: 442]. On the other hand, democratic elitists claim that civic involvement should be minimized, with the primary goal of leaving the political system and decisions about its shape in the hands of those who are better informed and who support the values of this system to a greater extent [Powell Jr 1982: 12]. Direct democracy cannot exist in isolation from indirect (representative) democracy; the former interacts with the latter and constitutes a significant component of it. Interestingly, direct democracy has attracted considerably less attention than representative one.

The concept of direct (participatory) democracy stresses direct participation in decision-making processes. Civic participation in the process of making decisions pertaining to the state, combined with higher education levels and the advancement of information technologies - in the opinion of the advocates of this concept - helps 
overcome all kinds of obstacles to promulgating the art of governance. The increased influence of individuals and their organizations on political processes reduces the risk of destabilizing democracy and increases its legitimization instead.

The current development of civilization has given rise to a number of questions about the further functioning and advancement of the democratic system for the exercise of power. The unprecedented transformations of political life we are witnessing today invite questions about whether the application of modern ICTs can facilitate the emergence of a new form of democracy (that could be compared to the formula of Athenian direct democracy) where the people would directly rule on the basis of modern mass media [Musial-Karg 2012: 131-132]. It has already been said that the modern democratic changes include a significant element of technology, which has contributed to the emergence of a new form of democracy - electronic democracy (e-democracy), a rather ambiguous term that defies clear interpretations. E-democracy is also defined as the implementation of information and communication technologies in order to increase civic involvement in democratic processes "both in terms of numbers and the form of actual impact individuals exert on the operation of public institutions" [Grodzka 2009: 1].

Civic involvement is believed to be a measure to counteract the weaknesses of and crisis in modern democracy. That is why the use of ICTs in the field of democratic self-determination and civic activization has triggered heated debates in relation to individuals, institutions and entire political systems [Masłyk 2007: 192]. The implementation of new technologies in politics for the purpose of information, communication and voting may contribute to increased activity of citizens who will be able to take part in political life faster and in a more convenient manner thanks to the transformation taking place in the modern world. The above-mentioned electronic democracy can, therefore, be considered in the context combining the functioning of a political system, including politically and socially active individuals, with ICTs [Musiał-Karg 2013]. Tomasz Masłyk is right, observing that

this relation is described by the term e-democracy applied alongside digital democracy [Norris 2000], cyberdemocracy [Poster 1995], the implementation of virtual polis [Ogden 1994], virtual democracy or information age democracy [Snider 1994]. Regardless of the terminology applied, however, using the word 'electronic' is most often related to the use of interactive technologies in social and institutional relations, and it is typically understood in this way [Masłyk 2007: 192].

Electronic democracy is a new way of communicating with citizens [London 1995: 33-34]. There are many definitions of this form of governance, but for the purpose of the present study the definition by Lewis A. Friedland has been adopted. 


\section{ELECTRONIC DIRECT DEMOCRACY}

The definition of electronic direct democracy can be designed by analogy to the definition above, and it can be understood as a form of governance where all eligible citizens participate in the process of political decision-making via new technologies.

Dariusz Gawin refers to this when he says that globalization has questioned not only the current perceptions of state functioning, but also the nature of everything political [Gawin 2003: 173]. Globalization processes have additionally led to a certain diffusion of power, shifting decision-making processes from national parliaments to other institutions, such as international entities or local governments. Additionally, the dynamic progress of new ICTs has contributed to the limitation, or even elimination, of some hindrances in the practice of direct democracy. Maria Marczewska-Rytko rightly observes that all this encourages more thorough scholarly reflection on the theory and the attempts to implement different solutions that make it possible to apply direct democracy tools in more countries than has been the case so far [Marczewska-Rytko 2010: 23-24].

Another thing worth bearing in mind in this context is the so-called crisis of democracy, manifesting itself not only in the malfunctioning of major state institutions, which do not properly perform their basic functions, but also in the decreased level of social trust in state entities and, most importantly, in the systematically falling voter turnout in national elections, referenda and supranational elections.

There are many claims that the application of new media in the process of political decision making, in elections as well as the procedures of direct democracy, such as referenda, consultations and popular initiatives, might help overcome the crisis of democracy and the adverse trend of decreasing voter involvement might be reversed thanks to the broader application of ICTs.

Direct democracy is approached as an alternative to representative democracy, although in practice they always operate side by side. In modern states, the democratic institutions of indirect democracy are increasingly often accompanied by the solutions typical of the participatory form of governance. Similarly to the extensive range of the institutions of direct democracy used by citizens in the process of political decision making, the electronic form of direct governance has ICT-based tools of exercising power that are or can be used by citizens as an instrument for co-participating in shaping political life and decisions. The practical dimension of new (electronic) forms of direct democracy suggests that the so-called digital direct democracy ${ }^{1}$ is the strongest form of direct democracy, in which people are involved in the decision-making processes. "Many advocates think that also important to this notion are technological enhancements to the deliberative process. Electronic direct democracy is sometimes referred to by many other names, such as open source governance and collaborative governance" [Nollen 2011].

\footnotetext{
1 In this text, the term "digital democracy" is used interchangeably with the term "electronic democracy".
} 


\section{ELECTRONIC REFERENDUM}

Electronic referendum (e-referendum, more broadly understood as electronic voting) is one of the tools of direct e-democracy. Electronic voting (e-voting) means voting by means of electronic technology in electoral processes and including at least the act of vote casting [Zbieranek 2005: 9]. According to the standpoint of the Internet Society Poland Association, information and communication technologies can be employed in voting in different manners and different stages of elections and referenda, for instance in the process of collecting, processing and visualization of results sent by electoral committees, when collecting and counting votes (using voting machines designed for this purpose) and during remote voting (via the Internet or SMSs - short text messages - sent from cellular phones) [Stanowisko Stowarzyszenia Internet Society Poland... 2007].

Literature on this subject identifies several basic types of electronic voting: voting via voting machines, computer voting and Internet voting [Musiał-Karg 2010: 128]. Apart from these types, two other terms are applied, namely $e$-voting and $i$-voting. ${ }^{2}$ Internet voting is divided into two categories: Internet voting at the polling place and remote Internet voting (via a "voting kiosk" or personal computer with an Internet connection) [Nowina-Konopka].

From the point of view of the topic of this paper, it is crucial that both e-voting and i-voting can be divided into two types, depending on the type of voting: e-elections (where new technologies are applied in the parliamentary, presidential or European elections, then ICT-based voting exemplifies a tool of representative democracy), e-referenda (where new technologies are employed at different stages of referenda and voting exemplifies a tool of direct democracy), i-elections (where the Internet is used at different stages of the parliamentary, presidential or European elections) or i-referenda (where the Internet is used for casting votes in referenda).

The United States is the global leader in terms of electronic voting, but a growing number of European states have also started discussions on modernizing the forms of civic participation in political decision-making. Although attempts to implement e-voting have failed in several countries, including Austria, many other countries are considering the implementation of electronic voting, primarily via the Internet, as an additional method for eligible voters to participate in voting procedures. Estonia is the first country in the world that has conducted national elections allowing for voting through the Internet.

Both European and global experience in terms of electronic referenda is rather modest. Switzerland is among the most advanced and experienced countries, having started the process of testing e-voting systems at the turn of the $21^{\text {st }}$ century, and implementing them in due course; these systems are primarily employed in referenda.

2 Both are strictly related to e-democracy, but e-voting has a considerably broader scope of meaning than $\mathrm{i}$-voting, which is a type of the former. 
Pilot projects were implemented in three cantons (Geneva, Neuchâtel and Zurich) from 2000 to 2005 . They were all based on the application of ICTs in voting procedures at the local, cantonal and federal levels. ${ }^{3}$

There are many reasons for adopting electronic or Internet voting in referenda (and elections) in Switzerland. The most prominent ones include the need to take advantage of technological progress in democratic procedures; facilitate voters' participation in referenda and elections and thereby boost voter turnout; add a new, more convenient and attractive form of participating in electoral procedures; and slash costs related to the organization and running traditional elections.

The specific character of Switzerland (including its geographical, linguistic and religious diversification, Swiss federalism and neutrality) combined with the unmatched level of development of direct democracy institutions make e-tools exceptionally attractive for Swiss voters. Their benefits are also appreciated by the Federal Council (federal government) which claims that e-voting can increase the effectiveness of voting in the frequent referenda (held at least four times a year) and boost participation, in particular in the youngest group of voters [Ladner, Felder, Schädel 2008: 2].

The implementation of the new form of voting in referenda in Switzerland has not produced any observable changes in terms of voter turnout, among other things. Whereas postal voting, introduced in the 1990s, did increase the level of civic participation by over a dozen percentage points in some elections or more, e-voting (e-referendum) does not appear to have comparable potential. An e-referendum appeals to those who hitherto voted by mail. Internet referenda are also attractive for those who never voted or voted infrequently and irregularly, but who have skills and experience in using computers. According to the survey conducted by the Centre for Research on Direct Democracy (c2d), once a voter chooses e-voting, they tend to repeat their choice in the next elections.

\section{ELECTRONIC POPULAR INITIATIVE}

The electronic popular initiative deserves to be mentioned alongside the e-referendum. Popular initiative is defined as "a request from the people to the people" [Banaszak, Preisner 1997: 153], and this definition seems to fully reflect the core of this form of participating in the legislative procedure. In modern times, popular initiative is provided for in the constitutions of numerous states. Also, countries that do not have long democratic traditions provide for popular initiatives in their respective constitutions.

3 These projects provide for a different scope of modern technologies to be used. They make it possible to vote in elections and referenda via the Internet as well as by sending a text message (SMS). 
There are many opinions of the advocates and proponents of electronic direct democracy suggesting that, in the face of dynamically developing modern technologies, it is necessary to implement and increasingly apply electronic legislative initiatives. Such a tool would facilitate collecting electronic signatures under a draft of a law, or voting by a constitutionally required number of eligible voters. One solution is to use a secure electronic signature verified by means of a valid qualified certificate. Any bill that garnered the required support would become a formal proposal, requiring the legislature to consider it (for instance, in a system providing for an indirect legislative initiative), or to fulfill voters' demands (for instance, in Switzerland, which provides for direct popular initiative, meaning that when a required number of voter signatures are collected, a general vote is automatically called).

It is of essential importance that electronic initiatives may be much easier to implement than electronic voting, because the former does not require the vote to be secret (anonymous), which makes the procedure considerably easier.

The Estonian solutions seem recommendable in this context. In order to cast their e-votes, Estonian voters need to have a new generation ID card, appropriate personal identification number (PIN), a computer with a connection to the Internet and a special reader for ID cards. Such a formula could work when signing a legislative initiative motion electronically.

Another good example comes from Switzerland, where advocates of electronic democracy state that collecting signatures for a popular initiative via a stand on the market seems to be rather an archaic thing. They "are aiming for half of signatures collected online". It is because wecollect.ch platform, which is a way of signing the initiative. "One click to select the topic, three fields to fill in (surname, first name, email)" and, a person receives a form that he or she can print out, sign, slip into a mailbox. As Marc-André Miserez argues, this

method of collecting signatures for the tools of direct democracy (initiatives, referenda) could well replace the traditional market stalls and door-to-door canvassing. In just a few days, wecollect.ch has already garnered more than 27,200 signatures in support of the three initiatives (soon four) it is promoting. The fact that these texts were launched by the leftwing Social Democratic Party and other left-wing groups - the website is on this side of the political spectrum - is immaterial. The right is bound to follow suit soon, if necessary by launching its own platform [Miserez 2016].

Using modern technologies to apply direct democracy tools can be perceived as a response to the essential problems of modern democracy. Direct e-tools for exercising power (reserved for direct democracy) can potentially enhance the transparency of governance, influence fuller civic participation in politics and counteract the social divisions emerging in connection with the advancement of new technologies [Antoine, Zucchi 2006]. 
It seems, therefore, trivial to note that the Web is an excellent means for voters to express their political opinions. Putting an electronic signature under a motion to consider a particular matter is an excellent expression of this.

\section{ELECTRONIC POPULAR ASSEMBLY}

Popular assembly is the third fundamental institution of direct democracy. This form of governance dates back to the ancient Greek poleis, and consists in the meetings of eligible voters who gather in the center of their municipality, typically once a year, in order to discuss and then vote on the matters of greatest importance for their location. Such assemblies may not seem entirely feasible in modern democratic states. The political practice of Switzerland, named the "pearl of direct democracy", proves otherwise, since they are organized in several of the smallest cantons (former semi-cantons) of the Swiss federation. Voting is usually open and follows discussions on a given project. The constitutions of Swiss cantons provide for certain deviations from this principle. According to Banaszak, Article 62, section 1 of the Constitution of the Unterwalden-Ob dem Wald canton [Verfassung des Kantons Unterwalden ob dem Wald..., Art. 62, section 1] stipulates that a secret vote may be held, and that the subject of the popular assembly may be limited solely to the election of specific entities or voting over a specific matter without earlier discussion [Verfassung des Kantons Appenzell Ausserrhoden ..., Art. 45, section 3].

Apart from assemblies at the cantonal level, Switzerland also holds local assemblies; in $80 \%$ out of ca. 2,800 municipalities the Landsgemeinde assembly (bringing together eligible voters interested in a given matter) is the most important way for citizens to make decisions pertaining to their places of residence.

The reason why voters' assemblies are an extremely rare phenomenon is the size of modern states. Assemblies typically occur in relatively small communities where it is possible to gather voters in one place and where they can be easily counted when voting.

Popular assemblies in modern Switzerland are facing a crucial issue of voter turnout. Although it is relatively difficult to analyze the participation of eligible voters in local assemblies (this is a result of scant information on such assemblies in individual municipalities) the conclusions developed by Andreas Ladner should be quoted.

Examining the data from 1988 and 1989, it can be seen that average participation in the 1988 assemblies amounted to $17.5 \%$, whereas a decade later this result fell by one percentage point to $16.5 \%$. Whereas the actual downturn of participation is relatively irrelevant, the low level of participation in general should raise concerns that such a small proportion of society is interested in the matters affecting their municipality and wants to make decisions in this regard [Ladner 2002: 823].

Against this backdrop, the application of modern methods may provide a solution to the problem of low participation in popular assemblies on the one hand, and the 
possibility to promote the institution of Landsgemeinde in other local communities in different countries on the other.

Electronic popular assemblies would facilitate discussions over pending projects and voting of more people than just those attending a traditional popular assembly. Setting up a dedicated online forum where only registered voters from a given municipality could participate could certainly be very useful. Posting all possible documents concerning the matters under discussion on the Internet would also be invaluable. This would mean an electronic assembly lasted not one, but at least several days. Voting in such an online local assembly could also take several days, thereby allowing interested voters to read the documents, take part in an online debate on each issue and, finally, cast their votes.

As for direct democracy and the implementation of new technologies (the Internet first and foremost), it has to be admitted that ICTs are changing the shape of direct governance and democracy in general. Modern technologies are perceived as a particularly significant platform that helps eliminate some limitations resulting from physical distance. Although cellular telephony is common and increasingly popular, due to digital technology, experts tend to value the Internet above all. One of the reasons is the asynchronic communication it ensures. Communicating through the Internet makes it possible to carry out a range of activities that do not require people to gather at a certain place and time. Therefore, the potential of the Internet can be said to exceed that of the traditional media of political communication, such as television, radio, newspapers and telephone [Wimmer 2004].

The instruments of electronic direct democracy listed in this section (e-referendum, popular e-initiative, and popular e-assembly) are not the only instruments of electronic democracy employed in modern countries. Electronic voting deserves particular attention (e-referendum is a specific form of e-voting) which is becoming increasingly important in modern democracies. The governments and parliaments of many countries are trying to adapt their democratic procedures to advancing new technologies, thereby making democratic institutions "more friendly" and "more citizen-accessible".

Apart from e-voting, there are also other new methods of spreading information and communicating, for instance, websites, where politicians and political parties inform voters about their activities, opinions and so on, discussion fora, chats, blogs, video blogs and social media allowing political actors to communicate with Internet users and exchange opinions on various matters.

\section{CONCLUSIONS}

Like many other aspects of modern human activity, political life is also changing due to the application of the Internet on an increasing scale, as evidenced by the emergence of such terms as electronic democracy (e-democracy) and electronic voting (e-voting). 
In the environment of new media, democracy as such is changing, as are its different forms, including direct democracy. The direct form of the exercise of power appears to be expanding, owing to ICT, among other things, on account of the elimination of the problem of physical distance between voters and polling stations, meaning more eligible voters will be able to take part in elections while not being required to come to polling stations in person.

Alongside democratic institutions, which are changing following the application of new media, profound changes are also occurring in the field of the methods of electoral campaigns (which largely concentrate on the Internet as a means of communication between politicians and voters), the conditions of electoral silence (which is practically uncontrollable in the Internet) and the methods of boosting voter turnout (by means of e-voting and online social campaigns encouraging greater participation in voting).

A direct democracy is a form of democracy in which referendums determine all or most of the policy decisions made by a government. This form of government takes decision-making out of politician's hands and transfers it to the people. Thomas Swan from Queen's University Belfast states that dynamic development of new technologies has made direct democracy a realistic option. He believes that the biggest potential has electronic voting that could improve the process of casting and counting ballots. What is more, electronic direct democracy would use the Internet and other ICTs to provide a space/platform for citizens to be involved in deliberating and voting on political issues [Swan 2015].

Jan A.G.M. van Dijk recalls that in the 1990s, one of the basic claims of digital democracy was that electronic forms of civic involvement (such as electronic polls, e- referenda) "would bring an era of direct democracy resembling citizen participation in the Athenian agora with modern means". He suggests that this should be changed when the era of Internet politics really makes its breakthrough. "Then, electronic polls, referenda and voting will be more influential. They will put the traditional representative system under growing pressure. Most likely, the future is to some kind of combination of representative and direct democracy on the basis of communication networks" [van Dijk 2012: 54].

The application of electronic techniques for the purpose of the exercise of democratic power few years ago was considered to be a revolution. Karen McCullagh [2003] argued that the interactive nature of the Internet could reinvigorate the democratic process and re-involve people in political decision-making processes. However, as it turned out, this was not so easy and one may admit that despite the rapid development of ICT, technical obstacles combined with, for instance, psychological limitations have extended the process of intensifying use of ICT (especially in less developed countries) to more than a dozen years, at least.

It should also be noted here that the rapid development of new media, and in particular the Internet, has a visible impact on democracy and political life on the one hand, and on the other - on the entire civilization, where the nature of human relations 
is changing, producing a new quality in many areas of social life. Although changes in political life due to the development of ICT cannot be regarded as revolutionary, the transformations in democratic governance (especially the improvement of electoral processes, casting votes, collecting signatures) can undoubtedly be regarded as an evolution that will make democratic processes more efficient.

\section{BIBLIOGRAPHY}

Antoine, P., Zucchi, G. 2006. Internetowe pamiętniki wysokich ranga polityków? Nie liczmy na to! (published 12.06.2006), transl. A. Gruszczyńska, www.cafebabel.eu/pl (access: 15.04.2015).

Banaszak, B., Preisner, A. 1997. Prawo konstytucyjne. Wprowadzenie, Wydawnictwo Uniwersytetu Wrocławskiego, Wrocław.

Barber, B. 1984. Strong Democracy. Participatory Politics for a New Age, University of California Press, Berkley-London.

Bartyzel, J. 2002. Demokracja, POLWEN, Radom.

Gawin, D. 2003. Spoleczeństwo obywatelskie w procesie globalizacji, [in:] Globalizacja i my. Tożsamość lokalna wobec trendów globalizacyjnych, R. Piekarski, M. Graban (eds.), Wydawnictwo Universitas, Kraków.

Grodzka, D. 2009. E-demokracja, "Infos. Zagadnienia społeczno-gospodarcze", Biuro Analiz Sejmowych, no. 14(61)/16 lipca 2009.

Konstytucja Rzeczypospolitej Polskiej z dnia 2 kwietnia 1997 r., Dz.U. [Journal of Laws] 1997, no. 78 item 483.

Ladner, A. 2002. Size and Direct Democracy at the Local Level: The Case of Switzerland, "Environment and Planning. Government and Policy", no. 20.

Ladner, A., Felder, G., Schädel, L. 2008. From E-Voting to Smart-Voting-E-Tools in and for Elections and Direct Democracy in Switzerland, Working Paper de I'IDHEAP no. 4.

London, S. 1995. Teledemocracy vs. Deliberative Democracy? A Comparative Look at Two Models of Public Talk, "Journal of Interpersonal Computing and Technology", vol. 3 (2).

Marczewska-Rytko, M. 2010. Idea demokracji bezpośredniej od okresu antycznego do czasów Internetu i globalizacji, [in:] Demokracja bezpośrednia. Wymiar globalny i lokalny, M. Marczewska-Rytko, A.K. Piasecki (eds.), Wydawnictwo UMCS, Lublin.

Masłyk, T. 2007. Aktywność obywatelska w spoleczeństwie informacyjnym. Perspektywa socjologiczna, doctoral dissertation, Katowice.

McCullagh, K. 2003. E-democracy: potential for Political Revolution?, "International Journal of Law and Information Technology", vol. 11 (2).

Miserez, M.-A. 2016. Direct Democracy Enters Digital Age, http://www.swissinfo.ch/eng/directdemocracy/ internet-canvassing_direct-democracy-enters-digital-age/42154122 (access: 15.06.2017).

Musiał-Karg, M. 2012. Electronic Democracy and Its Organization - a Revolution or a Modernization? The Example of E-Voting, "Politbook", no. 2.

Musiał-Karg, M. 2010. Gtosowanie elektroniczne - nowe wyzwanie dla demokracji?, "Przegląd Politologiczny" no. 4.

Musiał-Karg, M. 2013. Cisza wyborcza w dobie Internetu, "Przegląd Sejmowy", no. 3.

Nollen, P. 2011. Electronic Direct Democracy, http://participedia.net/en/methods/electronic-direct-democracy (access: 15.06.2017).

Norris, P. 2000. The Theories of Digital Democracy, http://www.hks.harvard.edu/fs/pnorris/Acrobat/digitalch5.pdf (access: 15.06.2017).

Novak, M. 2001. Duch demokratycznego kapitalizmu, Wydawnictwo W Drodze, Poznań. 
Nowina-Konopka, M., Elektroniczna urna, http://www.rpo.gov.pl/pliki/12066058070.pdf (access: 15.06.2017).

Ogden, M.R. 1994. Politics in a Parallel Universe. Is There a Future for Cyberdemocracy?, "Futures", vol. 26 (7).

Poster, M. 1995. Cyberdemocracy: Internet and the Public Sphere, University of California, Irvine, http:// faculty.humanities.uci.edu/poster/writings/democ.html (access: 27.07.2017).

Snider, J.H. 1994. Democracy On-Line, “The Futurist”, September/October, http://www.jhsnider.net/ MyWritings/94--TheFuturist--DemocracyOnline.pdf (access: 19.07.2016).

Stanowisko Stowarzyszenia Internet Society Poland w sprawie głosowania elektronicznego w wyborach powszechnych przyjęte przez Zarząd Stowarzyszenia w dniu 10 stycznia 2007 roku (uchwała Zarządu ISOC Polska nr 2/2007), 11.01.2007, Internet Society Poland, http://www.isoc.org.pl/200701/wybory (access: 27.07.2017).

Swan, Th. 2015.Would you like a Digital Direct Democracy?, https://hubpages.com/politics/Wouldyou-like-a-Digital-Direct-Democracy (access: 15.06.2017).

Świętojański, S. 1990. Wolność czy demokratyzacja?, "Słowo Narodowe", no. 4.

Pennock, J.R. 1979. Democratic Political Theory, Princeton University Press, Princeton.

Powell, Jr, G.B. 1982. Contemporary Democracies. Participation, Stability, and Violence, Harvard University Press, Cambridge.

Van Dijk, J.A.G.M. 2012. Digital Democracy: Vision and Reality, [in:] Public Administration in the Information Age: Revisited, I.Th.M. Snellen, M. Thaens, W.B.H.J. van de Donk (eds.), IOS Press, Amsterdam-Berlin-Tokyo-Washington D.C.

Verfassung des Kantons Appenzell Ausserrhoden, vom 30. April 1995, http://www.admin.ch/ch/d/ sr/1/131.224.1.de.pdf (access: 12.07.2017).

Verfassung des Kantons Unterwalden ob dem Wald, vom 19. Mai 1968, http://www.admin.ch/ch/d/ sr/131_216_1/index.html (access: 12.07.2017).

Wimmer, P. 2004. Elektroniczna demokracja, http://www.ucze.pl/InternetDemocracy.htm (access: 12.07.2017).

Zbieranek, J. 2005. W stronę reformy procedur glosowania w Polsce, “Analizy i Opinie”, no. 52.

\section{BIOGRAPHY}

Magdalena Musial-Karg, associate professor at the Department of Political Systems at the Faculty of Political Science and Journalism (Adam Mickiewicz University in Poznań). Since September 2016 - Vice-Dean for Research and Development. In October 2014, she was granted a 3-year stipend for the young excellent scientists funded by the Polish Minister of Science and Higher Education. Her research interests focus on direct democracy and the use of modern technologies (ICT) in democratic systems (mainly in electoral processes - e-voting). She is also dealing with the role of women in public space and with the cross-border cooperation in the Polish-German border area. She is the initiator and coordinator of the Research Group "Helvetic Initiative" (helwecja.amu.edu.pl). She is also involved in undertakings realized by the Center for Direct Democracy Studies at the University of Białystok. President of the Center for Research and European Education.

More information: http://musial-karg.pl; e-mail: magda.musial@interia.pl 